\title{
MODEL PENDIDIKAN KARAKTER BERBASIS NILAI-NILAI ISLAM UNTUK MEMBENTUK KARAKTER SISWA YANG TOLERAN
}

\author{
Muhsinin \\ ISNU (Ikatan Sarjana Nahdlatul Ulama), \\ Jawa Tengah, Indonesia. \\ muhsinin013@gmail.com
}

\begin{abstract}
Abstrak
Fokus dari tulisan ini adalah penerapan pendidikan karakter yang didasarkan pada nilai-nilai Islam. Pendidikan karakter berdasarkan Islam artinya pendidikan karakter yang mana komponennya mencakup pengetahuan moral, perasaan tentang moral, dan perbuatan moral. Moral-moral tersebut dijajaki dan dikembangkan berdasarkan nilai-nilai Islam. Penerapan pendidikan karakter ini bertujuan untuk membentuk karakter siswa yang islami dan toleran. Penelitian ini menggunakan studi kepustakaan. Hasil dari penelitian ini adalah penerapan pendidikan karakter membutuhkan keseriusan, pembiasaan, dan pembudayaan tentang nilai-nilai.
\end{abstract}

Kata kunci: pendidikan, karakter, nilai-nilai, Islam, akhlak, Islami

\section{Abstract}

CHARACTER EDUCATION MODEL BASED ON ISLAMIC VALUES TO CREATE THE ISLAMIC AND TOLERANT STUDENTS' CHARACTER. The focus of this writing is the implementation of character education that is based on Islamic values. Character education based on Islam means character education which their components include moral knowledge, moral sense and moral 
action. Those morals are explored and developed based on Islam values. The implementation of character education aims to establish an Islamic students' character and tolerant. This study uses library research. The result of this study is the implementation of character education needs seriousness, habituation, and civilizing the values.

Keywords: character, education, Islami, values, Islamic, character

\section{A. Pendahuluan}

Pendidikan sebagaimana tercantum dalam UUSPN N0. 20 tahun 2003 adalah bahwa "pendidikan bertujuan untuk mencapai berkembangnya potensi peserta didik agar menjadi manusia yang beriman dan bertakwa kepada Tuhan Yang Maha Esa, berakhlak mulia, sehat, berilmu, cakap, kreatif, mandiri, dan menjadi warga negara yang demokratis dan bertanggung jawab”. Dengan kata lain melalui pendidikan akan diharapkan tercipta peserta didik yang berkembang potensinya secara maksimal baik potensi intelektual (kognitif), afektif (etika, moral, spiritual, sikap, dan pribadi), serta psikomotornya sehingga semua potensi tersebut akan mendorong siswa menjadi manusia yang beriman, bertaqwa, berakhlak mulia, berilmu, cakap kreatif, mandiri dan bertanggung jawab.

Secara realitas pendidikan kita masih jauh dari harapan sebagaimana diharapkan seperti di atas. Dari segi kualitas pendidikan kita masih jauh dari negara-negara tetangga seperti tercantum dalam human development index (HDI) pada tahun 2010 bahwa Indonesia berada pada rank 108 dari 169 negara di bawah Singapura rank 27, Brunai rank 37, Malaysia rank 57, Thailand dan Filipina rank 92 dan 97. Sedang secara kualitas pendidikan kita juga masih banyak persoalan terkait dengan paradigma pendidikan dan keprofesionalan pendidik. Pendidikan kita masih berorientasi pada pengembangan intelektual belaka yang tidak diimbangi dengan kecerdasan lainya. Kualitas para guru di Indonesia juga terbilang masih rendah.

Hasil pendidikan yang hanya menghasilkan kecerdasan intelektual tersebut menyebabkan aspek kecerdasan lainnya menjadi hilang seperti kecerdasan rasa, emosional, spiritual dan lainya yang semua itu mendasari individu dalam bertindak dan berperilaku 
dengan mempertimbangkan nilai-nilai tersebut. Banyaknya penyimpangan yang mengindikasikan potret suram pendidikan kita adalah rendahnya moralitas, tidak peka dengan perbedaan, banyaknya konflik antar suku, budaya, lebih-lebih konflik agama, konflik agama tidak saja dari orang yang berbeda agama namun sesama agama pun bila sudah menyangkut perbedaan faham maka akan terjadi permusuhan, pertengkaran, saling membunuh dan seterusnya.

Potret suram pendidikan di atas terutama yang berkaitan dengan konflik agama sebenarnya dilatarbelakangi oleh pemahaman agama, militansi agama, fanatik beragama, fundamentalisme agama, dan juga hal-hal lain yang menyangkut agama. Sikap-sikap di atas akan memunculkan kepekaan untuk angkat bicara atau bertindak yang berlawanan dengan prinsip agama itu sendiri bila terdapat perselisihan. Agama yang sebenarnya menjadi penyejuk bagi pemeluknya berubah menjadi ajang untuk mudah disulut dan diadu domba untuk kepentingan tertentu yang mengatasnamakan agama.

Banyak pesantren dan kampus-kampus yang berlabel Islam juga sering menjadi sasaran dan pemicu terjadinya kerusuhan dan konflik-konflik sejenis. Padahal tempat-tempat tersebut seharusnya menjadi pusat percontohan, tempat tumbuhnya manusia-manusia berbudaya, sasana penggemblengan dalam bahasa Jawa disebut "kawah condro dimuko" yang akan menghasilkan generasi-generasi yang santun, berkepribadian dan berbudaya. Berdasarkan pengamatan sementara ditemukan banyak sekolah atau madrasah yang justru melahirkan manusia beragama yang fanatik, militan, fundamentalis yang dalam hidup kemasyarakatan tidak memberikan contoh beragama yang baik tapi malah lebih mudah menjadi anarkis, merasa lebih faham, gampang tersulut isu, kurang bisa menerima perbedaan karena beda agama dan seterusnya.

Pendidikan yang tidak mampu membentuk siswa yang memiliki kecerdasan rasa dan budi pekerti sebagaimana dalam potret suram di atas akan berdampak pada anak menjadi tidak dewasa dan tidak tanggung jawab. Bila siswa tersebut hidup dalam masyarakat yang majemuk, mereka kurang dapat menyesuaikan dengan kondisi 
kemajemukan masyarakat tersebut dan akhirnya akan mudah tersulut dan kurang dapat menghargai sebuah kemajemukan dalam hidup, kurang bisa menerima perbedaan yang terjadi apalagi kalau sudah menyangkut agama misalnya bagi mereka akan mudah bertindak anarkis.

Islam sebagai agama memiliki aturan dan sistem yang sempurna. Kesempurnaan itu menyangkut aturan manusia dengan Tuhan, manusia dengan sesama manusia, dan manusia dengan makhluk lainya (alam). Oleh karena itu Islam dinamakan agama rahmatan lil'alamin. Menghormati agama lain dan sesama pemeluk agama yang berbeda juga dianjurkan saling menghormati. Hal ini juga diabadikan dalam Q.S Al-Kafirun ketika terjadi perselisihan antar umat menyangkut agama, pesan ayat tersebut memberikan ajaran bagi kita untuk terciptanya kerukunan umat beragama, menghargai perbedaan keyakinan, toleransi sesama umat beragama dan saling tolong-menolong dalam kebaikan.

Berdasarkan nilai-nilai ajaran Islam yang sempurna tadi, untuk mengembalikan pengetahuan, pemahaman, dan perilaku beragama agar tercipta keharmonisan, kerukunan, serta kesahajaan dalam kehidupan dan hidup beragama, maka dibutuhkan pendidikan karakter berbasis nilai-nilai Islam sebagai model pemberdayaan pendidikan karakter dengan menginternalisasikan nilai-nilai ajaran Islam yang sebenarnya kaya dan syarat dengan nilai-nilai moral.

\section{B. Pembahasan}

\section{Pendidikan Karakter}

\section{a. Pengertian Pendidikan Karakter}

Kata karakter memiliki pengertian yang beragam ada yang menyamakan dengan watak, ada yang menganggap sifat atau juga kepribadian. Allport sebagaimana dikutip Suryabrata (1998: 2) mengatakan "character" yang artinya is personality evaluated, and personality is character devaluatedwatak atau karakter adalah kepribadian yang dinilai atau berkenaan dengan norma-norma. 
Kretschmer menjelaskan karakter adalah keseluruhan totalitas kemungkinan-kemungkinan bereaksi secara emosional dan volisional seseorang, yang terbentuk selama hidupnya oleh unsur-unsur dari dalam (dasar, keturunan, faktor-faktor endogen) dan unsur-unsur dari luar (pendidikan, dan pengalaman, faktor eksogen) (Suryabrata, 1998: 21) Dari dua pendapat di atas dapat disimpulkan bahwa karakter adalah menunjuk pada kepribadian yang dinilai berdasarkan nilai norma-norma yang baik sebagai reaksi secara emosional dan volisional seseorang yang terbentuk selama hidupnya oleh unsur dari dalam dan unsur dari luar.Menurut Berkowitz (2004: 2):

"Character is the complex set of psychological characteristics that enable an individual to act as a moral agent. In other words, character is multifaceted. It is psychological. It relates to moral functioning. In the first author's moral anatomy, seven psychological aspects of character are identified: moral action, moral values, moral personality, moral emotions, moral reasoning, moral identity, and foundational characteristics".

Karakter adalah himpunan yang kompleks tentang karakteristik psikologis yang memungkinkan seorang individu untuk bertindak sebagai agen moral. Dengan kata lain, karakter itu beragam. Hal ini terkait dengan fungsi moral. Tujuh aspek psikologis sebagai identifikasi karakter: yaitu tindakan moral, nilai-nilai moral, kepribadian moral, emosi moral, penalaran moral, identitas moral, dan karakteristik dasar. Jadi karakter berkaitan dengan keadaan psikologis untuk memberikan respon terkait dengan moralitas seseorang.

Pendidikan Karakter adalah langkah sengaja untuk memupuk kebajikan moral dan intelektual melalui setiap fase sekolah contoh kehidupan orang dewasa, hubungan antara teman sebaya, penanganan disiplin, resolusi konflik, isi kurikulum, proses pembelajaran, standar akademik yang ditetapkan, lingkungan sekolah, pelaksanaan kegiatan ekstrakurikuler, dan keterlibatan orang tua. Segala sesuatu yang terjadi dalam kehidupan sekolah adalah pendidikan karakter, karena semuanya mempengaruhi karakter siswa.

Pendidikan Karakter adalah term atau istilah yang secara longgar digunakan untuk menggambarkan bagaimana mengajar anakanak dengan cara yang dapat membantu mereka mengembangkan 
beragam kemampuan seperti moral, sipil, sopan santun, berperilaku yang baik, sehat, kritis, sukses, tradisional, sesuai dan atau diterima oleh kehidupan sosial. Penalaran moral/pengembangan kognitif, pendidikan kecakapan hidup, pendidikan kesehatan, pencegahan kekerasan, berpikir kritis, penalaran etis, dan resolusi konflik dianggap sebagai program yang gagal yaitu, "pendidikan agama", "pendidikan moral" dan "klarifikasi nilai".

Pendapat lain yang dikemukakan Lickona (Q-Anees, 2008: 98) menyimpulkan bahwa pendidikan karakter adalah upaya dengan sengaja menolong orang agar memahami, peduli akan dan bertindak atas dasar inti nilai-nilai etis. Seseorang dapat dikatakan berkarakter bila seseorang tersebut perilakunya sesuai dengan kaidah moral.

Terkait dengan pendidikan karakter Doni A Koesoema yang dikutip Q-Anees (2008: 100) menjelaskan ada dua paradigma dasar pendidikan karakter pertama, memandang pendidikan karakter dalam cakupan pemahaman moral yang sifatnya lebih sempit, kedua, melihat pendidikan dari sudut pandang Pemahaman isu-isu moral yang lebih luas. Pandangan ini memandang pendidikan karakter sebagai sebuah pedagogik, menempatkan individu yang terlibat dalam dunia pendidikan sebagai pelaku utama dalam pengembangan karakter. Dalam penelitian ini pendidikan karakter lebih dekat dengan paradigma yang kedua dimana pendidikan karakter sebagai proses pendidikan dan pembelajaran yang mengutamakan siswa sebagai agen perubahan karakter menuju good character dalam kehidupan dan bertanggung jawab dalam kehidupan sendiri dan bermasyarakat dengan nilai-nilai moral yang baik. Jadi, pendidikan karakter adalah pendidikan yang berupaya dengan sengaja untuk mengembangkan kemampuan siswa yang terkait dengan penalaran moral, tindakan moral, sopan santun, berperilaku yang baik, pengembangan kognitif, intelektual, kritis, yang sesuai serta dapat diterima dalam kehidupan sosial.

\section{b. Tujuan Pendidikan Karakter}

Pendidikan karakter bertujuan untuk membentuk karakter yang baik kepada peserta didik (siswa). Karakter tersebut menyangkut 
unsur nilai-nilai moral, tindakan moral, kepribadian moral, emosi moral, penalaran moral, identitas moral, dan karakteristik dasar dalam memberikan respon terkait dengan moralitas seseorang yang harus dimiliki siswa dan kemudian mampu menerapkannya dalam kehidupan sehari-hari.

\section{c. Tahap-Tahap Penalaran Moral}

Tahap-tahap penalaran moral oleh Thomas Lickona. (1983, 1985, 1994) dijelaskan secara rinci sebagai berikut:

\begin{tabular}{|c|c|c|}
\hline \multirow{2}{*}{$\begin{array}{l}\text { Stage } 0 \text { : } \\
\text { EGOCENTRIS } \\
\text { REASONING } \\
\text { (preschool year-around } \\
\text { age 4) }\end{array}$} & What's Right & I Should get my own way \\
\hline & Reason to be good & $\begin{array}{l}\text { To get rewards and avoid } \\
\text { punishments }\end{array}$ \\
\hline \multirow{4}{*}{$\begin{array}{l}\text { Stage } 1 \text { : } \\
\text { UNQUESTIONED } \\
\text { OBEDIENCE } \\
\text { (Around Kindergarten } \\
\text { age) Diragukan lagi } \\
\text { Kepatuhan (sekitar usia } \\
\text { TK) }\end{array}$} & & \\
\hline & What's Right & I Should Do what I'm told. \\
\hline & & \\
\hline & Reason to be good & To stay out troble \\
\hline \multirow{2}{*}{$\begin{array}{l}\text { STAGE 2: WHAT'S IN- } \\
\text { IT-FOR ME FAIRNESS } \\
\text { (early elementary } \\
\text { graden) }\end{array}$} & What's Right: & $\begin{array}{l}\text { I Should look out for my } \\
\text { self but be fair to those who } \\
\text { are fair to me }\end{array}$ \\
\hline & Reason to be good: & $\begin{array}{l}\text { Self interest: What's in it } \\
\text { for me? }\end{array}$ \\
\hline \multirow{2}{*}{$\begin{array}{l}\text { STAGE 3: } \\
\text { INTERPERSONAL } \\
\text { COMFORMITY } \\
\text { (midle-to-upper } \\
\text { elementary grades and } \\
\text { early to min teens }\end{array}$} & What's Right & $\begin{array}{l}\text { I Should be anice } \\
\text { person and live up to the } \\
\text { ekspectation of people I } \\
\text { know care about }\end{array}$ \\
\hline & Reason to be good & $\begin{array}{l}\text { So others will think well of } \\
\text { me (social approval) and I } \\
\text { cant think well of my self } \\
\text { (self-estern) }\end{array}$ \\
\hline
\end{tabular}




\begin{tabular}{|c|c|c|}
\hline $\begin{array}{l}\text { STAGE 4: } \\
\text { RESPONSIBILITY TO }\end{array}$ & What's Right & $\begin{array}{l}\text { I Should fulfill my } \\
\text { responsibilities to the social } \\
\text { or value system I feel part } \\
\text { of }\end{array}$ \\
\hline $\begin{array}{l}\text { THE SYSTEM } \\
\text { (hight school years or } \\
\text { late teens) }\end{array}$ & Reason to be good & $\begin{array}{l}\text { To keep the system from } \\
\text { falling a part and to } \\
\text { maintain self-respect as } \\
\text { somebody who meets my } \\
\text { obligations }\end{array}$ \\
\hline \multirow{2}{*}{$\begin{array}{l}\text { STAGE 5: } \\
\text { PRONCIPLED } \\
\text { CONSCIENCE }\end{array}$} & What's Right & $\begin{array}{l}\text { I should show the greatest } \\
\text { possible respect for the } \\
\text { rights and dignity of every } \\
\text { individual person and } \\
\text { should support a system } \\
\text { that protects humman right }\end{array}$ \\
\hline & Reason to be good & $\begin{array}{l}\text { The obligation of } \\
\text { conectience to act in } \\
\text { accordance with the } \\
\text { principle of respectfor all } \\
\text { humman being }\end{array}$ \\
\hline
\end{tabular}

\section{d. Prinsip Dasar dalam Pendidikan Karakter}

Menurut Q-Anees (2008: 103) menyebutkan bahwa prinsip dasar pendidikan karakter meliputi: 1) manusia adalah makhluk yang dipengaruhi dua aspek yaitu pada dirinya memiliki sumber kebenaran dan dari luar dirinya ada juga dorongan atau kondisi yang mempengaruhi kesadaran; 2) karena menganggap bahwa perilaku yang dibimbing oleh nilai-nilai utama sebagai bukti dari karakter, pendidikan karaktertidak meyakini adanya pemisahan antara roh, jiwa, dan badan.; 3) pendididkan karakter mengutamakan munculnya kesadaran pribadi peserta didik untuk secara ikhlas mengutamakan karakter positif; 4) pendidikan karakter mengarahkan peserta didik untuk menjadi manusia ulul albab yang tidak hanya memiliki kesadaran diri tetapi juga kesadaran untuk terus mengembangkan diri, memperhatikan masalah lingkungannya, dan memperbaiki kehidupan sesuai dengan pengetahuan dan karakter yang dimilikinya; 
5) karakter seseorang ditentukan oleh apa yang dilakukannya berdasarkan pilihan. Setiap keputusan yang diambil menentukan akan kualitas seseorang dimata orang lain.

Sedang Lickona (dalam Kemendiknas, 2011: 11) mengemukakan ada sebelas prinsip dasar pendidikan karakter yang efektif yaitu sebagai berikut:

1) Pendidikan Karakter mempromosikan nilai-nilai etika inti sebagai dasar karakter yang baik seperti merawat, kejujuran, tanggung jawab, keadilan, dan menghormati diri sendiri dan orang lain.

2) Karakter harus didefinisikan secara komprehensif untuk mencakup pemikiran, perasaan, danperilakuyang efektif, luas mencakup aspek kognitif, emosional, dan perilaku hidup moral. Karakter yang baik terdiri dari pengertian, peduli, dan bertindak atas nilai-nilai etika inti.

3) Pendidikan karakter yang efektif memerlukan pendekatan yang disengaja, proaktif, dan komprehensif yang mempromosikan nilai-nilai inti dalam semua fase kehidupan sekolah. Sekolah berkomitmen untuk melihat pendidikan karakter diri mereka sendiri melalui lensa moral dan melihat bagaimana hampir segala sesuatu yang terjadi di sekolah mempengaruhi nilai-nilai dan karakter siswa.

4) Sekolah harus menjadi komunitas yang peduli dalam mewujudkan karakter yang baik melalui internalisasi nilainilai moral.

5) Untuk mengembangkan karakter, siswa membutuhkan kesem-patan untuk tindakan moral dalam domain etis intelektual, siswa adalah pembelajar yang konstruktif, mereka belajar paling baik dengan melakukan.

6) Pendidikan karakter yang efektif termasuk kurikulum akademik yang bermakna dan menantang yang menghargai semua pelajar dan membantu mereka berhasil. Karakter pendidikan dan pembelajaran akademik tidak harus dipahami sebagai bidang yang terpisah, melainkan harus ada hubungan yang kuat dan saling mendukung.

7) Pendidikan Karakter harus berusaha untuk mengembangkan motivasi intrinsik siswa. Kepentingan subyek, keinginan 
untuk bekerja sama dengan siswa lain, dan pemenuhan menerima perbedaan secara positif dalam kehidupan orang lain atau di sekolah atau masyarakat.

8) Staf sekolah harus menjadi pembelajaran dan komunitas moral di mana semua berbagi tanggung jawab untuk pendidikan karakter dan berusaha untuk mematuhi nilai-nilai inti yang sama yang membimbing pendidikan siswa keinginan untuk mengembangkan komunitas sekolah yang peduli? Refleksi dengan alam ini adalah kondisi yang sangat diperlukan untuk mengembangkan kehidupan moral.

9) Pendidikan karakter memerlukan kepemimpinan moral dari kedua staf dan mahasiswa. Pendidikan karakter untuk memenuhi kriteria yang diuraikan sejauh ini, harus ada pemimpin (seorang kepala, administrator yang lain, seorang guru memimpin).

10) Sekolah, orangtua, dan anggota masyarakat sebagai mitra penuh dalam upaya pembangunan karakter.

11) Evaluasi pendidikan karakter harus menilai karakter sekolah, fungsi staf sekolah sebagai pendidik karakter, dan sejauh mana siswa mewujudkan karakter yang baik. Pendidikan karakter yang efektif harus menyertakan usaha untuk menilai kemajuan.

Tiga jenis yang memerlukan perhatian:

a) Karakter sekolah: Sampai sejauh mana sekolah menjadi komunitas yang lebih peduli? Hal ini dapat menilai, misalnya, dengan survei yang meminta siswa untuk menunjukkan sejauh mana mereka setuju dengan pernyataan seperti, "Siswa di sekolah (kelas) menghormati dan peduli satu sama lain," dan "ini sekolah (kelas) adalah seperti keluarga. “

b) Pertumbuhan staf sekolah sebagai pendidik karakter: seberapa memiliki staf yang dewasa-pengajar, administrator, dan personil yang bisa mendorong pengembangan karakter, keterampilan untuk melaksanakannya, konsisten dengan kebiasaan bertindak atas kapasitas mereka berkembang sebagai pendidik karakter.

c) Karakter siswa: sejauh mana siswa mewujudkan pemahaman, komitmen, dan tindakan atas nilai-nilai 
etika inti. Sekolah dapat, misalnya, mengumpulkan data tentang perilaku berbagai karakter siswa mencakup: kehadiran siswa, perkelahian pelanggaran sekolah dan seterusnya dan sekolah juga dapat menilai tiga domain karakter (mengetahui, merasakan, dan berperilaku) melalui kuesioner anonim yang mengukur keputusan moral siswa (apakah kecurangan pada tes yang salah), komitmen moral ("apakah Anda menipu jika Anda yakin Anda tidak akan tertangkap") dan perilaku moral yang dilaporkan sendiri (berapa kali kamu mengkhianati tes atau tugas utama dalam setahun terakhir). Kuesioner tersebut dapat diberikan pada awal inisiatif karakter sekolah untuk mendapatkan data dasar dan lagi pada poin nanti untuk menilai kemajuan.

\section{e. Metode Pendidikan Karakter}

Supriadi (2009) dalam Program Pendidikan Karakter di Lingkungan BPK PENABUR Jakarta menjelaskan metode penanaman karakter sebagai berikut: 1) Mengajar untuk berpikir. 2). Menguatkan nilai diri yang bertumpu pada penerimaan kita oleh Tuhan karena kasih-Nya (Christ based self-esteem). Berdasarkan hal ini kita mengasihi orang lain. 3). Membantu menguasai perasaan, baik terhadap diri sendiri maupun terhadap orang lain. 4). Mengembangkan lebih banyak sikap kristiani. 5). Membuka diri terhadap hubungan saling mempedulikan antarsesama. 6). Mengembangkan karunia untuk melayani dan memimpin. 7). Mengajarkan untuk setia dalam pelayanan pendidikan.

\section{Nilai-Nilai Islami dalam Pendidikan Karakter}

Dalam konteks Islam pendidikan karakter atau biasa disebut dengan istilah "moral" atau akhlak dalam Islam telah ada sejak Islam itu ada karena diutusnya Nabi Muhammad saw. di muka bumi ini adalah untuk menyempurnakan akhlak yang mulia, dimana pada zaman itu bangsa Arab masih menjadi bangsa yang "biadab", bangsa "jahiliyah", dan bangsa yang "tidak berbudaya". Bersama dakwah Rasulullah saw. sedikit demi sedikit menjadi berubah baik hingga sekarang. Hal ini menjadi bukti keberhasilan rasulullah saw dalam 
mendidik kaum jahiliyah menjadi kaum yang berakhlakul karimah, menjadi kaum yang "berbudaya”, dan kaum yang "berperadaban”.

Dalam perspektif Islam inilah akan dibangun kembali pondasi moralitas peserta didik dalam pendidikan Islam agar tumbuh menjadi manusia yang mulia, manusia yang memberi manfaat bagi makhluk lainya yaitu menjadi ibadurrahman kata Ibnu Qoyyim yang selalu berperan dalam kemajuan sebagaimana fungsinya sebagai kholifah fil ardl.

Akhlak atau moral dalam Islam dibangun di atas kebaikan dan kejelekan sedang kebaikan dan kejelekan (dalam menentukan kebaikan dan keburukan sesuatu) itu tempatnya ada di dalam fitrah salimah dan akal yang lurus, maka setiap sesuatu yang dianggap baik oleh fitrah salimah dan akal yang lurus ini ia termasuk bagian dari akhlak yang baik lagi mulia, dan setiap sesuatu yang dianggap jelek, maka ia termasuk kedalam akhlak yang buruk. Akan tetapi akal dan fitrah kadang-kadang lemah dalam menghukumi tentang kebaikan dan kejelekan sesuatu (Ibnu Qoyyim dalam Hasan Aly Al-Hijazi, $\mathrm{tt}$.). Berdasarkan kondisi kekuatan fitrah salimah dan akal yang lurus yang menjadi penentu dalam berperilaku seseorang, maka dalam diri seseorang tersebut dibutuhkan arahan, bimbingan, dan petunjuk yang baik agar fitrah salimah dan akal yang lurus memiliki kekuatan untuk selalu melakukan perbuatan yang sesuai dengan fitrah salimah dan akalnya yang lurus. Disinilah peran pendidikan untuk membudayakan perilaku yang baik melalui keputusan fitrah salimah dan akal yang lurus tadi sehingga menjadi karakter yang baik.

Dalam tulisan ini akan dikaji tentang nilai-nilai Islami yang dapat dikembangkan dalam pendidikan karakter yang meliputi:

a. Arus aqidah, ibadah, syariah, dan Akhlak.

Akidah sebagai sistem keyakinan yang dimanifestasikan melalui wujud ibadah sebagai penghambaan diri kepada tuhan dengan jalan penguasaan syariat sebagai media yang harus dikuasai sedang akidah, syariah dan ibadah merupakan bagian dari sistem peribadatan yang harus dibuktikan dengan perilaku (perbuatan) yang baik. Jadi akhlak adalah cerminan dari ketiga komponen (akidah, ibadah, 
dan syariah). Ibnu Qoyyim sebagaimana di kutib Hasan bin Aly alHijazi (tt) menjelaskan bahwa ibadah adalah puncak ketundukan yang tumbuh karena pengetahuan hati akan keagungan Dzat yang disembah. Ibadah merupakan pembuktian (amaliah) dari sebuah akidah. Apabila akidah benar-benar tertancap dalam dada seorang hamba, maka ibadah yang dilakukan akan benar-benar ikhlas dan bila jiwa seorang hamba telah menjadi jiwa yang mulia karena kedalaman akiah maka kebaikan jiwa tersebut akan menyebar kepada orangorang di sekitarnya atau tercermin akhlak yang baik. Ibadah dalam Islam merupakan refleksi dari akidah Islam jika akidah Islamiyah itu mencakup seluruh sendi kehidupan dan manusia, maka ibadahpun harus mencakup seluruh sendi yang ada. Semua bentuk ibadah kepada Allah apabila dikerjakan sesuai dengan cara dan syariat yang telah ditentukan Allah, maka akan membuahkan beberapa manfaat besar seperti menumbuhkan ketenangan jiwa. Beliau menambahkan bila ibadah yang telah disyariatkan oleh Allah tidak menjadikan seseorang itu memiliki akhlak yang mulia dan jiwa sosial yang tinggi maka ibadah tersebut masih cacat atau kurang benar atau belum dipahami hakekat dan kaifiyahnya yang benar sebagaimana telah disyariatkan oleh Allah swt.

Berdasarkan keterkaitan antara aspek akidah, ibadah, syariah dan akhlak dalam arus beragama maka dalam pendidikan akhlak nilai keempat aspek di atas harus digali dan dikembangkan sehingga menjadi sebuah karakter yang tetap pada diri siswa. Jadi untuk membentuk anak yang berakhlakul karimah salah satu yang harus digarap adalah memberdayakan kekuatan akidah pada siswa, ibadah, syariah dan akhlak.

\section{b. Insān Kämil, Ulul albāb, kholifah fil-Ardl}

Insan kamil adalah tujuan dari pendidikan Islam, artinya pendidikan Islam akan mencetak generasi muslim menjadi manusia yang mampu menjadi pengganti (kholifah) Allah di muka bumi dalam konteks fungsi manusia tersebut senada dengan istilah insan kamil. Konsep insan kamil terkait dengan konsep kholifah yaitu jabatan yang diberikan kepada manusia. Hal ini diungkap dalam Q.S 
Muhsinin

Al-Baqoroh(2): 30) yang artinya sebagai berikut:

"Ingatlah ketika Tuhanmu berfirman kepada paramalaikat, Sesungguhnya aku hendak menjadikan seorang kholifah di muka bumi. Mereka berkata, "Apakah Engkau akan menjadikan di muka bumi itu orang yang akan membuat kerusakan padanya dan menumpahkan darah, padahal kami senantiasa bertasbih dengan memuji dan menyucikan engkau? (Q.S AlBaqoroh(2): 30).

Pesan Al-Qur'an di atas memberikan pelajaran bagi kita bahwa pertama, untuk dapat menunaikan tugas kekhalifahan di muka bumi tidak cukup dari golongan malaikat sebagai hamba yang selalu bertasbih dengan selalu memuji dan mensucikan Allah. Kedua, Tuhan lebih memahami tentang manusia, manusia lebih memiliki potensi untuk dapat menjadi kholifah dimuka bumi. Ketiga, untuk dapat memerankan kholifah di muka bumi tersebut dibutuhkan modal yaitu ilmu, hanya manusia yang mampu mempelajari dan memiliki ilmu tersebut.

Ulul Albāb memiliki ciri selalu merenungkan ciptaan Allah di langit dan di bumi dan berusaha mengembangkan ilmu sedemikian sehingga karunia Allah itu dapat dilipat gandakan nikmatnya. Dalam konsep ulul albab terdapat dua aspek penting yaitu tafakur dan tasyakur, tafakur lebih berorientasi pada usaha untuk merenungkan ciptaan Allah di langit dan di bumi dan berusaha untuk menemukan hukum-hukum untuk kemudian digunakan dalam mencipta hal-hal yang baru, sedang tasyakur merujuk pada bagaimana menggunakan atau memanfaatkan nikmat Allah dengan secukupnya dan menggunakan akal pikiranya agar kegunannya bertambah.

Adapun ciri-ciri ulul albab sebagaimana dijelaskan Jalaluddin Rahmat yang dikutip Q-Anees (2008:54) adalah sebagai berikut: 1) bersungguh-sungguh mencati ilmu termasuk di dalamnya bersungguh-sungguh menafakuri dan menasyakuri ciptaan Allah; 2) mampu memisahkan yang jelek dari yang baik walaupun ia harus sendirian memperhatikan kebaikan itu dan walaupun kejelekan itu dipertahankan oleh sekian banyak orang; 3) kritis dalam mendengarkan pembicaraan, pandai menimbang-nimbang ucapan, teori, proposisi, atau dalil yang dikemukakan orang lain; 4) bersedia 
menyampaikan ilmunya kepada orang lain untuk memperbaiki masyarakatnya; 5) tidak takut pada siapapun kecuali kepada Allah.

Berdasarkan konsep insan kamil, kholifah fil ardl dan ulul albab ketiganya memiliki kesamaan dalam peran dan fungsinya sebagai manusia yang harus menjaga memperbaiki dan mengembangkan alam ini sebaik-baiknya. Dan di dalam menjaga dan mengembangkan alam ini dapat diperankan oleh insan kamil sebagai manifestasi kholifah ataupun peran manusia sebagai agen perubahan yang selalu menyeimbangkan alam ini agar tetap lestasi walaupun semua kondisi di alam ini sangat tidak tetap zatnya. Untuk bisa menyeimbangkan alam ini, maka menjadi peran manusia sebagai ulul albab yang selalu mengembangkan science dan teknologi atau dalam bahasa pendidikannya menggunakan istilah tafakur dan tasyakur.

Konsep insan kamil, khalifah dan ulul albab dapat dijadikan sebagai nilai-nilai Islam yang harus dikembangkan dalam rangka pendidikan karakter. Insan kamil sebagai capaian tertinggi dalam pendidikan karakter yang dalam capaian sederhananya yaitu tercapainya manusia yang saleh dan utuh, saleh dengan dirinya dan saleh dengan orang lain atau dengan sosialnya.

\section{c. Konsep tentang Fitrah}

Dalam pandangan Islam konsep fitrah memiliki banyak arti dan penafsiran Syekh Tantawi Jawhari yang dikutip Burhanuddin mengemukakan konsep fitrah berdasarkan hadis yang artinya, "Setiap manusia yang dilahirkan dalam keadaan suci dan rergantung orangtuanya anak tersebut menjadi Yahudi, Nasroni, atau Majusi. Jadi beliau memandang manusia lahir dalam keaaan iman juga pikiran manusia sebagai lembaran kosong yang siap menerima stimulasi yang baik atau juga yang jelek tapi secara alamiah manusia memiliki kecenderungan untuk berbuat baik, bila lingkungan memberikan stimulasi yang baik, maka manusia akan menjadi baik.

Senada dengan pendapat Syekh Tantawi Jawhari bahwa fitrah manusia dengan konsep Din (agama) sebagaimana terdokumentasi dalam Q.S Al-Rum; 30) yang artinya sebagai berikut: 
"Maka hadapkanlah wajahmu dengan lurus kepada agama Allah, tetapkanlah atas fitrah Allah yang telah menciptakan manusia menurut fitrah itu. Tidak ada perubahan pada fitrah Allah (itulah) agama yang lurus, tetapi kebanyakan manusia tidak mengetahui" (Q.S AlRum(30): 30).

Ayat di atas memberikan pemahaman kepada kita bahwa makna fitrah manusia dihubungkan dengan agama Allah. Jadi manusia dilahirkan dengan kecenderungan untuk mengakui dan meyakini atau bertauhid kepada Allah. Tentang hakekat fitrah ini lebih tegas di jelaskan dalam Q.S Al-A'Raf (17): 172) yang artinya:

"Dan ingatlah ketika Tuhanmu mengeluarkan keturunan anak Adam dari sulbi mereka dan Allah mengambil kesaksian kepada jiwa mereka (seraya) berfirman: Bukanlah Aku ini ilahmu? Mereka menjawab: Betul (Sesungguhnya Engkau adalah Illah kami) Kami menjadi saksi agar pada hari Kiamat engkau tidak mengatakan: sesungguhnya kami tidak pernah diberi peringatan (terhadap ke-esaan Allah)".'(Q.S Al-A'Raf (17): 172)

Ayat di atas memberikan pengertian kepada kita bahwa manusia sesuai dengan fitrahnya telah memberikan kesaksian tentang dirinya terhadap ke-esaan Allah artinya pada saat kejadiannya manusia sebenarnya sudah mengakui dan meyakini tentang ketauhidan kepada Allah Azza wajalla. Jadi jika dikemudian hari mereka menjadi tidak beriman atau mengingkari kepada Allah maka sesungguhnya bukan karena fitrahnya namun karena pengaruh atau stimulasi dari lingkungan yang membentuk kondisi itu menjadi demikian.

Dalam dunia pendidikan kata fitrah yang memiliki arti agama atau ketauhidan tersebut dapat disepadankan dalam makna potensi yang bersifat pembawaan atau yang dibawa manusia sejak lahir. Manusia membawa potensi beragama dan juga berpotensi selalu mengesakan Tuhannya. Namun potensi tersebut sebagaimana dalam hadis di atas akan tergantung pada lingkungan yang mempengaruhinya.

Kata fa abawāhu Yuhawwidānihi.... dalam hadis di atas memberikan pemahaman tentang pentingnya pendidikan agar fitrah manusia tadi tetap baik dan menjadi lebih baik. Dalam konteks pendidikan karakter, nilai-nilai fitrah manusia tadi juga 
memiliki relevansi yang kuat dalam rangka pembentukan karakter moral atau akhlak yang baik melalui penanaman nilai-nilai fitrah manusia. Dengan memberikan stimulasi tentang nilai-nilai Islami yang menyangkut pembentukan moral pada anak, maka anak akan terbentuk moral yang baik pula. Moral yang baik disini yang sesuai dengan akhlak rasulullah saw. Jika akhlak rasulullah sebagaimana diceritakan sayyidatina Aisyah adalah al-Quran, maka akhlak yang sesuai dengan ajaran Islam adalah akhlak yang sesuai dengan Al- Qur'an.

Hubungan dengan nilai fitrah di atas bahwa ada secerca untuk menjadikan anak itu menjadi berakhlak seperti dalam ajaran Al-Qur'an bila pengaruh pendidikan dan juga lingkungan keluarga memberikan stimulasi pendidikan moral yang bernuansa Islami sehingga nilainilai yang ditanamkan tadi menjadi karakter yang melekat, dan jika karakter yang melekat tadi adalah karakter Al-Qur'an maka karakter tersebut adalah karakter yang Qur'ani. Demikian sebaliknya jika nilai-nilai yang mempengaruhi adalah nilai-nilai yang tidak baik maka karakter yang terbagun adalah karakter yang tidak baik pula.

\section{Pendidikan Karakter dalam Islam}

Berdasarkan pengertian tentang pendidikan karakter yang sudah diuraikan di depan, bahwa pendidikan karakter adalah upaya dengan sengaja menolong individu siswa agar memahami, peduli akan dan bertindak atas dasar inti nilai-nilai etis. Seseorang dapat dikatakan berkarakter bila seseorang tersebut perilakunya sesuai dengan kaidah moral. Jadi inti dari pendidikan karakter adalah moralitas sebagai bangunan karakter yang harus dimiliki siswa sebagai modal dalam bersikap dan berperilaku dalam hidup dan kehidupannya, baik dalam hidup sehari-hari berkaitan dengan dirinya maupun hidup bermasyarakat.

Pendidikan karakter dalam Islam berarti pendidikan karakter sebagaimana dalam pengertian secara umum yang didasarkan pada segi-segi ajaran Islam sebagai substansi materi yang produknya adalah karakter Islami yaitu karakter yang sesuai dengan ajaran Islam. Dalam konteks pendidikan karakter, yang menjadi unsur utama 
adalah peserta didik atau siswa sedang siswa secara naluriah dan alamiah dalam pandangan Islam sudah memiliki potensi "fitrah" atau dasar pembawaan yang baik namun sifat pembawaan dasar tadi tidak secara otomatis menjadi baik tanpa pendidikan. Dengan demikian semua fitrah peserta didik tadi juga harus dikawal dengan pendidikan agar menjadi baik. Hal ini diperkuat dengan hadis nabi yang menegaskan bahwa tugas kenabian Muhammad Rasulullah adalah untuk menyempurnakan akhlak yang mulia. Kata menyempunakan berarti meningkatkan atau mengembangkan yang pada hakekatnya sudah ada potensi berakhlak baik sebelumnya. Dalam hadis lain juga dijelaskan yang intinya bahwa manusia dilahirkan dalam keadaan fitri, bergantung pada bagaimana lingkungannya yang akan membentuk kefitrian itu dalam warna tertentu dan khas sesuai dengan lingkungan tersebut.

Berdasarkan kondisi tentang hakekat peserta didik tersebut bahwa manusia sudah memiliki modal dasar yang baik dan modal tersebut juga tergantung dimana lingkungan itu akan mempengaruhi, maka ada kekuatan-kekuatan yang perlu ditekankan dalam rangka mempengaruhi potensi dasar tadi menjadi baik yaitu melalui internalisasi nilai-nilai melalui pendidikan Islam. Pendidikan agama Islam secara substansial memiliki empat aspek materi yaitu Qur'an hadis, akidah akhlak, feqih, dan sejarah peradaban Islam. Keempat materi tersebut dimaksudkan agar siswa mampu menjadi ibadurrahman sesuai tujuan pendidikan Islam. Keempat materi tadi memiliki peran dan fungsi yang berlainan dalam rangka membentuk dan membangunan karakter yang Islami, namun semuanya kait mengkait satu sama lain.

Keempat material pendidikan Islam tersebut yang menjadi modal dasar secara lengkap untuk membentuk karakter siswa yang Islami. Salah satu karakter Islami yang terpenting saat ini yang kental dengan istilah kesalihan pribadi dan kesalehan sosial. Kesalehan pribadi berkaitan dengan hubungan baik dengan Tuhan sedang kesalehan sosial menyangkut hubungan baik dengan lingkungan (masyarakat dan alam sekitar). 
Islam pada dasarnya dibagi menjadi tiga bagian yaitu akidah (keyakinan), syariah (peribadatan atau praktek ibadah), dan akhlak (pengamalan agama). Ketiganya saling berkaitan, akidah sebagai sistem keyakinan yang akan menggerakkan diri melalui action ibadah sesuai keyakinan tersebut sedang akhlak sebagai pengejawantahan dari akidah dan syariah terwujud dalam perilaku amaliah sehari-hari yang baik. Ancok (1995) menjelaskan bahwa akhlak atau pengamalan agama yaitu bagaimana individu berelasi dengan dunianya, terutama dengan manusia lain. Dalam Islam dimensi ini menyangkut perilaku suka menolong, bekerjasama, berderma, menyejahterakan dan menumbuhkembangkan orang lain, menegakkan keadilan, berlaku jujur, memaafkan, menjaga lingkungan hidup, menjaga amanat dan sebagainya. Singkatnya dimensi akhlak dalam Islam melingkupi dimensi vertikal dan horizontal atau tercipta kesalehan pribadi dan kesalehan sosial.

\section{Penerapan Pendidikan Karakter Islami di Sekolah atau Madrasah}

Pendidikan karakter yang ideal dalam Islam tadi masih menjadi menara gading yang belum memiliki makna yang berarti bila hanya sebatas ide dan teori saja, untuk itu diperlukan bagaimana implementasinya dalam praksis pendidikan di sekolah maupun di madrasah.

Madrasah sebagai praktek pendidikan Islam sudah ada sejak Islam itu ada seperti juga pendidikan karakter itu sudah ada sejak Islam itu ada. Namun dalam perjalanan sejarah pendidikan Islam itu sendiri juga menampakkan wajahnya dalam berbagai variasi dan bentuk seperti pada kondisi saat ini dimana banyak terjadi berbagai isu dan konflik baik yang menyangkut kualitas pendidikan Islam maupun adanya konflik-konflik seputar agama yang banyak dipicu oleh kurangnya pemahaman dalam menyikapi persoalan-persoalan diversity dalam beragama. Munculnya berbagai kericuhan, dekadensi moral, kekerasan antar agama, radiakalisme, dan sebagainya sebenarnya mengisyaratkan pada kita untuk segera mereformulasikan 
pendidikan Islamyang dapat menciptakan manusia yang dapat memberikan kedamaian, kesejukan saling menyayangi, mengasihi, menyantuni sesama manusia walaupun berbeda agama sekalipun.

Untuk menciptakan manusia yang santun dan berbudaya serta mau dan mampu menerima perbedaan adalah menjadi fokus pendidikan Islam dewasa ini. Oleh karenanya konsep pendidikan karakter sebagaimana terurai di atas harus dapat diterapkan dalam pendidikan Islam. Secara praksis penerapan pendidikan karakter tidak berdiri sendiri dalam kurikulum tapi menjadi bagian dari muatan pada masing-masing bidang studi yang diajarkan di madrasah atau sekolah. Seperti kata Wakil Menteri Pendidikan Nasional dalam sebuah diskusi di Maarif Institute. Fasli menuturkan bahwa pendidikan karakter pada implementasinya tidak akan dimasukkan menjadi kurikulum yang baku, melainkan dikembangkan melalui tindakan dalam proses belajar. Dia mengimbau agar setiap lembaga pendidikan membiasakan pendidikan karakter dalam kesehariannya sehingga tercipta budaya sekolah yang berkarakter.

Menurut penulis implementasi pendidikan karakter dalam pendidikan Islam dapat ditempuh dengan langkah-langkah sebagai berikut:

a. Mendesain pendidikan karakter melalui penataan muatanmuatan yang akan diterapkan pada masing-masing bidang studi yang akan dipelajari oleh murid.

b. Mengeksplorasi nilai-nilai yang dapat dikembangkan pada masing-masing bidang studi sehingga menjadi bagian dari pendidikan karakter. Seperti penanaman nilai-nilai keimanan, ketakwaan dan ibadah pada bidang Akidah Akhlak dengan membudayakan praktek ibadah dalam kesehariannya serta membiasakan sikap dan perilaku yang baik terkait dengan hikmah keimanan dan ibadah tersebut akan membentuk akhlak yang baik.

c. Pembiasaan dan pembudayaan pada masing-masing bidang nilai-nilai yang ditekankan pada setiap bidang studi.

d. Pengintegrasian seluruh nilai-nilai moral dan agama dalam 
kehidupan sosial melalui praktek kehidupan sehari-hari di lingkungan sekolah, keluarga dan masyarakat.

e. Penyadaran bagi para guru dan pendidik untuk selalu merealisasikan pendidikan karakter dan berusaha memahami tentang ilmu-ilmu pendidikan untuk suksesnya pendidikan karakter berbasis Islam.

f. Evaluasi dan kontrol yangn berkelanjutan untuk memperbaiki pelaksanaan pendidikan karakter berbasis nilai-nilai Islami.

\section{Simpulan}

Pendidikan karakter Islami menjadi jihad besar bagi para pendidik di lingkungan pendidikan Islam. Karena tanpa kegigihan dan usaha yang sungguh-sungguh pendidikan karakter ini tidak akan berhasil dengan baik. Pendidikan karakter membutuhkan keseriusan dalam prakteknya karena semua itu dibutuhkan pembiasaan dan pembudayaan yang berkelanjutan tentang nilai-nilai baik yang diajarkan tadi, artinya tidak sekali diajarkan satu nilai langsung jadi tapi membutuhkan waktu membiasakan yang berulang-ulang sehingga menjadi karakter pada siswa.

Pendidikan karakter dalam pendidikan Islam tidak dapat ditawar lagi karena rapuhnya bangsa ini banyak disebabkan karena pendidikan tidak membekali dan menciptakan manusia yang berbudi pekerti yang baik namun lebih mengedepankan pencapaian kulaitas akademik kuantitatif yang pada akhirnya hanya dicapai pengetahuan atau kecerdasan intelektual belaka. Dan pengalaman menunjukan bahwa pendidikan yang mengedepankan pengembangan intelektual selama ini telah membawa pendidikan kita pada potret suram yang kurang baik. 
Muhsinin

\section{DAFTAR PUSTAKA}

Ancok, Djamaludin dan Fuat Nashori Suroso. 1995. Psikologi Islami. Yogyakarta: Pustaka Pelajar.

Berkowitz, Marvin W. and Melinda C. Bier. 2004. Research Based Character Education. The ANNALS of the American Academy of Political and Social Science 2004 Force Academy and a professor of psychology at Marquette University.

Hitipeuw, Immanuel dan Raka Joni. 2010. Wawasan Pendidikan Makro Pendidikan. Malang: Universitas Negeri Malang

Lickona, Thomas. 1994. Raising Good Children, New York. Used by permission for one year from Random House. pp. 11-15, A Bantam Book.

Lickona, Thomas dkk. (tt). Eleven Principles of Effective Character Education.

Megawangi, Ratna. 2007. Character Partenting Space. Read! Publising House Bandung: Mizan

Ryan, Kevin. 2002. The Six E's of Character Education, Center for the Advancement of Ethical and Character.

Sekretariat Diktoral Jendral Pendidikan Dasar Kementrian Pendidikan Nasional.2011. Mencari Karakter Terbaik dari Belajar Sejarah. Jakarta: Kementrian Pendidikan Nasional.

Sekretariat Diktoral Jendral Pendidikan Dasar Kementrian Pendidikan Nasional.2011. Pendidikan Karakter dalam Pembelajaran PKn. Jakarta: Kementrian Pendidikan Nasional

Supriadi, Djudjun Djaenudin. 2009. Kerohanian dan Karakter BPK PENABUR. Jakarta. No. 25 THN. VII Tabloit Edisi Maret April 2009

Supriadi, Djudjun Djaenudin. 2009. Program Pendidikan Karakter di Lingkungan BPK Penabur. Jakarta. No. 25 THN. VII Tabloit Edisi Maret - April 2009 
Model Pendidikan Karakter Berbasis Nilai-Nilai Islam...

Suryabrata, Sumadi. 1998. Pengembangan Alat Ukur Psikologis. Jakarta: Dirjen Dikti Depdikbud.

UUSPN No 20 Tahun 2003, Jararta: Diknas

Q-Anees, Bambang dan Adang Hambali. 2008. Pendidikan Karakter berbasis Al-Qur'an. Bandung: Simbiosa Rekatama. 
Muhsinin

halaman ini bukan sengaja dikosongkan 